\title{
Experiências das viajantes naturalistas durante o século XIX e as representações do Brasil oitocentista ${ }^{1}$
}

\author{
The experience of traveling naturalists and representations \\ of nineteenth century Brazil
}

\author{
RAICK DE JESUS SOUZA \\ Casa de Oswaldo Cruz | COC/Fiocruz
}

\begin{abstract}
RESUMO O objetivo central deste trabalho é analisar as experiências expedicionárias dos viajantes naturalistas durante o século XIX ao Brasil e o papel das impressões deixadas por esses intelectuais acerca da natureza e do povo brasileiro, com ênfase nos relatos feitos pelas naturalistas. O caminho metodológico é a reconstrução histórica das viagens a partir dos espaços descritos e das representações das espécies vivas observadas. Dessa forma, busca-se contribuir com os estudos que analisam a circulação de pessoas, produtos e ideias durante o Oitocentos brasileiro. O papel desempenhado pelas mulheres na produção das ciências será o eixo central desta investigação.
\end{abstract}

Palavras-chave naturalistas - viajantes - mulheres - Brasil Imperial

\begin{abstract}
The central objective of this paper is to analyze the experience of traveling naturalists that were present in Brazil during the nineteenth century, and the role of the impressions left by these intellectuals about Brazilian nature population, with special emphasis on the reports made by women naturalists. Our approach is based on the reconstruction of the fieldwork experience from the descriptions of spaces visited and the representations of the living species observed. We thus seek to contribute to studies that analyze the circulation of people, products and ideas during the nineteenth century in Brazil. The role of women in the construction of science is at the heart of this investigation.
\end{abstract}

Keywords naturalists - travelers - women - Imperial Brazil

\section{Introdução}

Em geral, os estudos históricos sobre as ciências no Brasil foram dominados desde a década de 1950 pela questão da institucionalização; tratava-se de uma história preocupada sobretudo em explicar como determinados contextos sociais, econômicos, políticos e culturais possibilitaram a implantação e o desenvolvimento da "ciência" como campo institucionalmente organizado. Recentemente, a atenção voltou-se para os processos de produção, apreensão e difusão dos saberes, com maior ênfase nas atividades de grupos ou indivíduos que estiveram ligados a este campo. 0 objetivo central desta investigação é analisar às experiências das viagens naturalistas ao Brasil durante 0 século XIX, em especial, a partir das impressões deixadas pelas naturalistas estrangeiras.

As primeiras impressões sobre este vasto território considerado atualmente como Brasil foram realizadas ainda durante o período colonial, sobretudo pelos jesuítas portugueses, bem como por viajantes espanhóis, franceses, 
holandeses e seguido por ingleses. "Com a chegada da corte ao Brasil, teve início o ciclo das grandes expedições de viajantes e naturalistas estrangeiros, que se manteve até o final do século XIX". ․ Estes viajantes, em especial os viajantes-naturalistas, manifestavam em seus relatos o poder evocativo e o deslumbramento diante da exuberância da natureza tropical. $\underline{3}$

Ao longo da história, diversos foram os viajantes naturalistas europeus que empreenderam viagens exploratórias pelo vasto território brasileiro, a fim de não apenas conhecer como tornar público a diversidade das espécies, bem como arrolar as riquezas naturais disponíveis no "Novo Mundo". Dentre estes inúmeros viajantes, destacam-se nomes como Carl Friedrich Philipp von Martius, Johann Baptist von Spix, Maximilian de Wied von Neuwied, Langsdorff, Francis de Castelnau, Alexander von Humboldt, Auguste de Saint-Hilaire, Louis Agassiz, Alfred Wallace e Charles Darwin para citarmos apenas alguns que entre os anos do século XIX passaram e produziram relatos sobre o Brasil. Conforme Ana Maria Belluzzo,

[...] Com a vinda da corte portuguesa para o Brasil, especialmente após a independência, chegam ao país artistas profissionais, diletantes com domínio do desenho. Ancoram no Rio de Janeiro passageiros de viagens turísticas pelo mundo. Possuem uma visão educada na estética do pitoresco e buscam desfrutar paisagens características. Mais do que a descrição naturalista, predominam entre eles a abordagem romântica do passeio pelos arredores e pelos jardins, a visão do homem "original" na floresta virgem ou a forte sensação da grandiosidade do universo. Não se pode, portanto, adotar um conceito a priori de paisagem. Seria melhor indagar o que o Brasil do século XIX pode dar a ver e quais modelos apreciativos teriam possibilitado o recorte do mundo sensível e a configuração daquilo a que se convencionou chamar paisagem. Em outras palavras, perguntar como é que determinados modos de apreciação dos europeus do século XIX se juntaram com estímulos da topografia, da geografia, da vegetação e da vida humana no Brasil, passando a tipificar uma paisagem brasileira..$^{4}$

De acordo com Heloisa Bertol Domingues, no Brasil, o processo de construção política e ideológica da "nação" esteve estritamente relacionado com o processo de institucionalização das ciências naturais. 0 governo imperial brasileiro durante o século XIX incentivou fortemente o processo de exploração natural, organizando e implementando comissões científicas que se dirigiram a diversas regiões do país a fim de estudar sua composição geográfica, geológica, botânica, zoológica e etnográficas. Grandes incentivos foram dados a exploradores estrangeiros no intuito de colaborarem com este processo. $\cdot \underline{5}$

Um dos empreendimentos historiográficos mais significativos no que se refere a uma concepção geral das representações do Brasil para os estrangeiros foi o dossiê temático produzido em 1996 pela Universidade de São Paulo. Como bem nos lembra Ana Maria Belluzzo, uma das marcas do conhecimento científico sobre o Brasil que tira proveito da observação visual, foi deixada pela concepção paisagística de Alexander von Humboldt. Em sua concepção, a visão pictórica pretende abarcar o todo, considerando a interdependência das formas de vida, diferente do recurso gráfico preconizado por Carlos Lineu, que individualizava, fragmentava e isolava figuras da natureza. 0 modelo de geografia botânica arquitetado por Humboldt foi levado a cabo por outros personagens, como por exemplo Martius e tantos outros viajantes de formação alemã e relacionados com a Academia de Ciências Francesa. Para a autora, o tema indissociável da experiência do viajante do século XIX é a paisagem. $\underline{\underline{6}}$

Compreenderemos aqui o papel do viajante-naturalista na concepção de uma natureza brasílica. Para isso frequentaremos algumas das investigações acadêmicas produzidas nas últimas décadas oriundas do campo historiográfico da História das Ciências que se debruçaram sobre estes viajantes e suas impressões acerca do Brasil Oitocentistas. Este estudo nem de longe pretende esgotar esta discussão ou mesmo se propõe a ser balanço historiográfico. Ele nada mais é do que a tentativa de refletir acerca de um tema de interesse particular - as viagens dos naturalistas ao Brasil durante o século XIX e suas respectivas representações - com a bibliografia disponível sobre este objeto, incorporando uma atenção maior as impressões e trajetórias das viajantes naturalistas. No primeiro momento discutiremos o modelo preconizado pelas naturalistas (paisagismo humboldtiano) na exposição da natureza brasileira e em seguida, o papel das viajantes naturalistas na produção de ciências durante o século XIX. Além de realizar uma análise de algumas pinturas das naturalistas Maria Graham e Marianne North. 


\section{As viagens exploratórias e a concepção humboldtiana de paisagem}

A partir do verbete sobre história natural presente na Encyclopédie, ou dictionnaire raisonné des sciences, des arts et des métiers de Diderot e D’Alembert, podemos ter uma noção do papel a ser exercido pelo naturalista. Cabia a ele compreender todo o universo, sendo seu objeto de estudo tão extenso quanto a própria natureza. Os astros, o ar, os animais, os vegetais e mineiras do globo terrestre em sua superfície e profundidade. Entre estes animais estavam inclusos os seres humanos, dos quais o comportamento e a língua eram características a serem classificadas, comparadas e analisadas. ${ }^{\underline{7}}$

De acordo com Simon Schwartzman, a descrição da natureza do Novo Mundo, em especial a sua fauna, sua flora, suas riquezas minerais e a variedade de povos e comunidades, vão constituir o núcleo central das atividades científicas desenvolvidas ao longo de todo 0 século XIX. $\underline{-}$ Segundo o pesquisador, duas das principais instituições científicas inauguradas no Brasil durante o século XIX (o Museu Nacional e o Jardim Botânico) foram frutos deste empenho em conhecer as espécies naturais. ${ }^{-9}$ Foi, em especial, a partir da independência do Brasil dos laços coloniais com Portugal que, as atividades científicas e instituições puderam expandir os seus trabalhos. Schwartzman lembra os apelos feitos, a partir de 1821, aos naturalistas estrangeiros que para cá se dirigissem e que partes de suas coletas fossem doadas a fim de aumentar os acervos das instituições científicas anteriormente citadas. Datam deste mesmo período o início das permutas sistemáticas de coleções e exemplares com os países estrangeiros..$^{10}$

Maria Margaret Lopes afirmou que foi durante esse mesmo período que os museus de história natural passaram a representar no Ocidente um importante papel na construção das identidades nacionais, não sendo diferente no contexto imperial brasileiro. $\frac{11}{}$

Conforme Nancy Stepan, o século XIX pode ser considerado o século por excelência para os empreendimentos naturalistas, em especial para as viagens exploratórias. ${ }^{12}$ Em um de seus trabalhos canônicos para o estudo das viagens naturalistas a autora afirmou que um dos fatores que explicariam essa primazia do século XIX seriam as oportunidades políticas associado com os interesses econômicos. Tanto a Europa imperialista quanto as antigas colônias passaram a desenvolver com base em acordos de colaboração uma maior circulação de pessoas, ideias e produtos. Outro fator de extrema importância diz respeito aos condicionantes cultuais; tanto as atividades dos naturalistas quanto dos viajantes passaram por sensíveis transformações, tanto no que concerne as suas dinâmicas internas, quanto nas suas representações simbólica externas. 0 conhecimento do mundo natural possibilitaria as grandes potências melhor explorar as riquezas disponíveis em suas colônias, como também possibilitavam as antigas colônias ascenderem ao posto de nações civilizadas. Conhecer para crescer estava na ordem do dia. $\frac{13}{}$ Diversas transformações nas técnicas de coleta, bem como de conservação e de transporte possibilitaram uma melhor circulação das ideias, dos produtos e de seus envolvidos. Um dos aspectos mais relevantes apontados nesse estudo foi o papel desempenhando pelos colaboradores locais, muitas vezes negligenciados por este tipo de historiografia que prioriza sempre o papel desenvolvido pelos viajantes e estudiosos responsáveis por analisar os materiais coletados.

Lorelai Kury alegou que uma das decisões mais difíceis para os naturalistas oitocentistas eram de fato as viagens - longas, custosas e em muitos casos extremamente perigosas - àqueles sujeitos acostumados com os gabinetes de estudo e aos luxuosos salões europeus. ${ }^{14}$ Outro aspecto relativamente importante era o valor simbólico destas aventuras para a comunidade científica em formação, uma vez que, não era unânime entre a comunidade a relevância das viagens aos estudos científicos. $\frac{15}{}$ A autora afirmou que 0 exemplo mais conhecido do naturalista para quem a experiência da viagem era insubstituível é certamente Alexander von Humboldt. Seus argumentos eram de que as “[...] impressões estéticas experimentadas pelo viajante em cada região fazem parte da própria atividade científica e não podem ser substituídas por descrições ou amostras destacadas dos lugares onde foram coletadas". " ${ }^{16}$ Desta forma, a viagem passa a ser encarrada pela história natural como uma etapa necessária no processo de transformação da natureza em ciência, mesmo que houvesse ainda opositores a nova técnica.

Naturalistas e aventureiros como Humboldt, Saint-Hilaire e Philipp von Martius compartilhavam de visões semelhantes com relação ao tipo de sociabilidade partilhadas pelas plantas brasileiras; para os autores, uma das características mais marcantes do tipo de vegetação encontrada nesta parte do globo era a variedade de espécies coexistindo em 
um mesmo tipo de ecossistema. Para figuras como Martius, homens, plantas e animais compõe um quadro complexo do que seria a diversidade brasílica, assim como para o seu predecessor Humboldt. Sendo assim, na visão desses naturalistas, as ciências e as artes deveriam caminhar pari passu no processo de reconstrução dos microcosmos:

A iconografia resultante das viagens científicas do século XIX costuma representar cenas consideradas típicas da vida nos trópicos, onde a natureza e os indígenas têm papel predominante. O pintor Louis de Choris, que passou pelo Sul do Brasil em 1815, procurou retratar traços naturais e humanos no interior de um mesmo conjunto. Em uma das poucas ilustrações que fez sobre o Brasil, insere em uma paisagem de Santa Catarina pássaros, répteis, plantas, relevo local e o que seria um "brasileiro típico".17

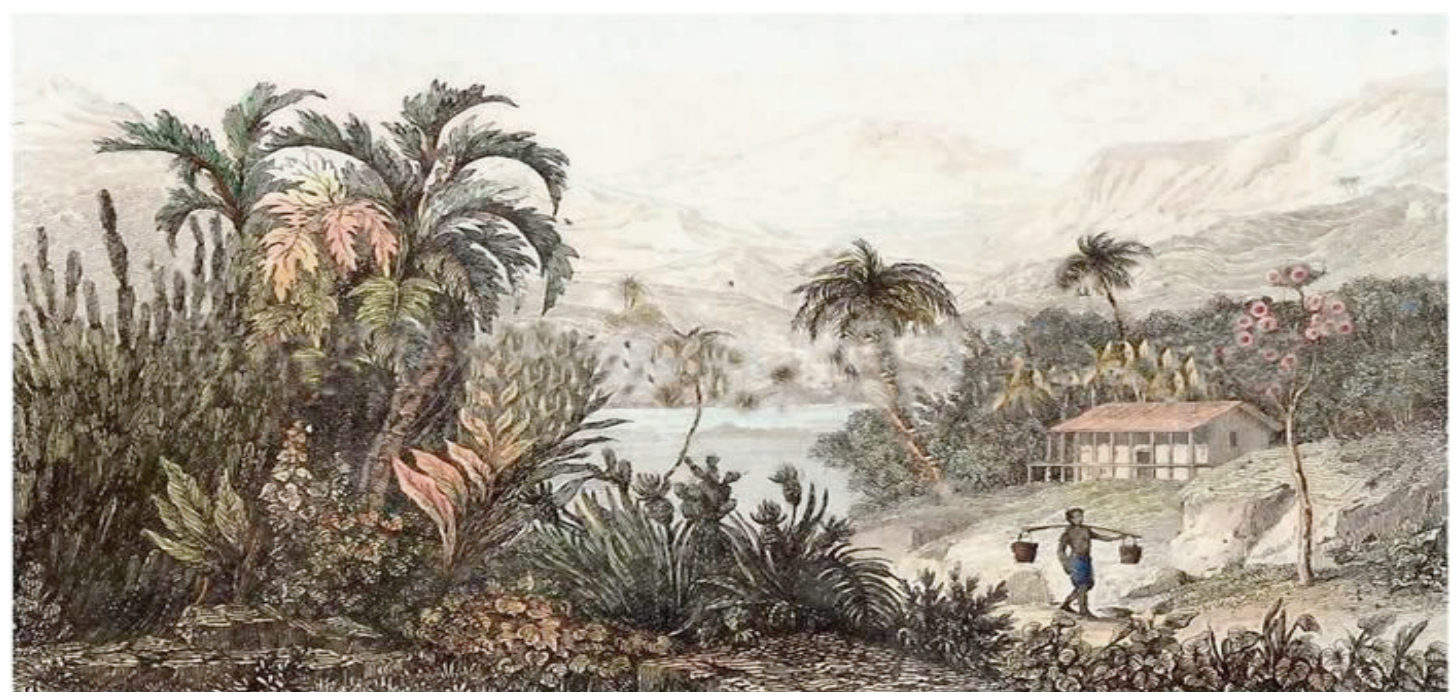

Figura 1. Representação da Ilha de Santa Catarina, pintada pelo artista plástico francês Louis Choris em 1815.

Disponível em: http://www.sunrisemusics.com/turismo05.htm

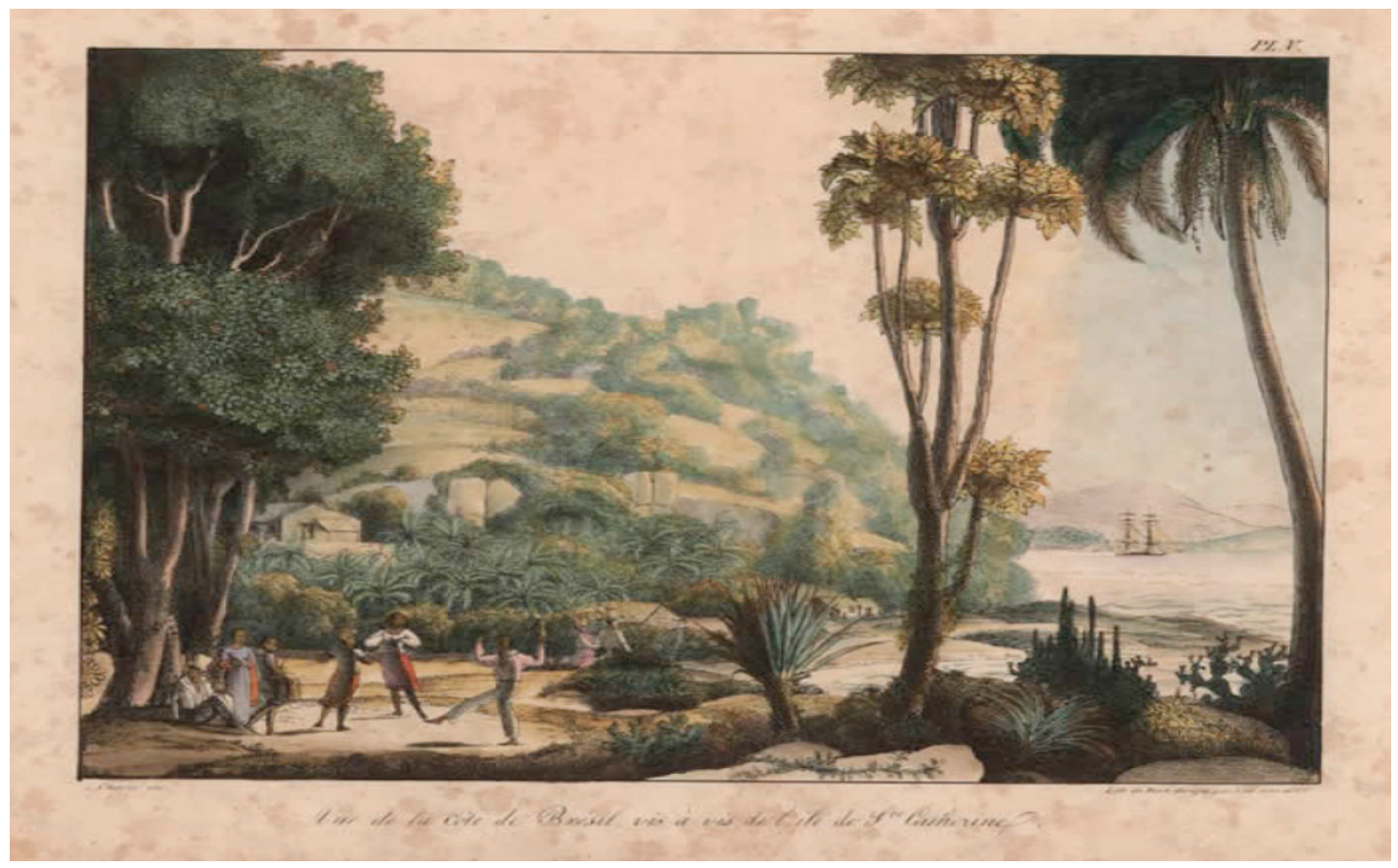

Figura 2. Representação da Ilha de Santa Catarina, pintada pelo artista plástico francês Louis Choris em 1815.

Disponível em: http://www.sunrisemusics.com/turismo05.htm 
Nas Figuras 1 e 2 é possível percebermos a representação deixadas pelo artista Louis Choris da llha de Santa Catarina na viagem exploratória do brigue Rurik, na qual estavam presentes 27 pessoas, entre elas três naturalistas e o pintor francês. A viagem exploratória comandada por Otto von Kotzebue e financiada pelo Conde de Ramanzoff tinha como objetivo descobrir uma passagem entre o Pacífico Norte e o Atlântico. Mesmo que o objetivo não tenha sido alcançado, os relatos de viagens e as representações iconográficas serviram para ampliar o conhecimento sobre os territórios visitados, entre eles o Sul do Brasil. Encontramos nas duas imagens uma das principais marcas das representações oitocentistas do Brasil, a multiplicidade de espécies vivas coexistindo em um mesmo microcosmo. Este mesmo tipo de representação pode ser encontrado nos relatos de diversos outros viajantes que estiveram por aqui durante 0 século XIX, sejam eles naturalistas ou mesmo artistas em comissões ou viagens exploratórias particulares. $\frac{18}{}$

Dessa forma, concordamos com Lorelai Kury quando ela afirma que os diversos artifícios representativos, tais como iconografia, textos e espécies, foram largamente utilizados para criar uma atmosfera realista do que seria a natureza e a vida nos trópicos. Conforme Kury,

Assim, o modelo humboldtiano orientou uma determinada maneira de retratar os lugares percorridos pelos viajantes. A descrição das fisionomias particulares permitia, em aparente paradoxo, integrar os fenômenos particulares ao cosmo. Diversos tipos de representação - iconográficas, textuais e material museológico compõem o quadro de um lugar específico. Esse quadro retrata sua essência. A ciência dos viajantes busca atingir o que está por trás da variedade e da profusão dos fenômenos. Martius escolhe com precisão as fisionomias retratadas em seus inúmeros livros, muitas vezes desenhadas ou pelo menos esboçadas por ele mesmo ou por artistas conceituados que vieram ao Brasil, como Rugendas e Thomas Ender. Os momentos retratados são especiais, únicos e típicos ao mesmo tempo. Únicos, porque foram vividos e observados pelo próprio viajante ao longo de suas andanças. Típicos, porque os fenômenos descritos ocorrem ali sempre sob as mesmas circunstâncias. A fisionomia de um lugar depende da quantidade, da variedade e da sociabilidade das plantas e dos animais, assim como do tipo de relação que os habitantes locais estabeleceram com a natureza ao longo do tempo. É como se cada fisionomia contivesse uma parte da alma do Brasil. $\underline{19}$

A justificativa para a utilização destes diversos artifícios seria o desejo de compreender a totalidade cósmica, ao mesmo tempo que o particular representaria o todo. A autora esclarece que para o naturalista do século XIX, a ciência deveria buscar descrever a totalidade de elementos que atuavam em um fenômeno local; seria como se cada parte contivesse o todo. "Uma fisionomia particular seguiria a mesma lógica de relações harmônicas e de simpatias que, supunha-se, regiam a vida cósmica" ${ }^{20}$ Este desejo de representar fielmente 0 vivido insere na lógica da ciência romântica do século XIX, na qual

[...] o viajante-naturalista do século XIX parece não ter hesitado entre considerar a irreprodutibilidade de sua experiência e entre fornecer registros fiéis do que viu, ouviu e sentiu. Nesse sentido, o estilo pitoresco das representações iconográficas das paisagens e costumes dos lugares visitados poderia ser considerado como estilo científico. A ciência das viagens foi uma forma de apreensão das relações entre ambiente e seres vivos; a profusão de registros produzida pelos diversos tipos de viajante, uma maneira de tornar a experiência da viagem reprodutível. 121

Alguns destes naturalistas não se prestaram apenas a investigar a diversidades das espécies e riquezas mineiras. Um bom exemplo do que foi mencionado encontra-se na expedição de Saint-Hilaire que assim como a fauna e flora, descreveu os hábitos dos portugueses e dos nativos brasileiros. Da mesma forma, na expedição chefiada por Louis Agassiz entre os anos de 1865 e 1866, que contou com a auxílio de sua esposa, Elizabeth Cary Agassiz, podemos encontrar valiosas descrições das habitações, dos hábitos cotidiano e da variedade dos povos moradores do território brasileiro. Em suas "impressões gerais" os expedicionários tecem considerações acerca de temas variados, tais quais: a religião e o clero brasileiro; a educação; o papel da Faculdade de Direito e de Medicina; a Escola Central; as escolas primárias; a biblioteca pública e os museus; o papel do Instituto Histórico e Geográfico; as relações sociais e domésticas dos habitantes do país; a agricultura nas zonas de vegetação; o manejo na cultura do café e do algodão; a variedade 
dos produtos florestais do Amazonas; as subdivisões territoriais do vale do Amazonas; e a emigração estrangeira. Pela forma no qual o relato de viagem foi escrito, na primeira pessoa, e com referências indiretas ao suíço, somos levados a crer que a maior parte das descrições transpostas dos locais observados e dos contatos estabelecidos tenham sido produzidos pela esposa do viajante. ${ }^{22}$ Suas alegações finais são claros indícios do determinismo climático e racial que animavam os seus pensamentos:

\begin{abstract}
Ao lerem este rápido apanhado, dirão os meus amigos do Brasil que eu medi parcimoniosamente o elogio de suas instituições e critiquei sem benevolência o seu estado social? Espero que não. Estaria longe de minhas intenções se deixasse ao leitor a impressão de que parti do Brasil com outros sentimentos que não sejam uma calorosa simpatia por este país, uma fé profunda em seu futuro e em sua prosperidade e uma gratidão pessoal muito sincera para com os seus habitantes. Reconheço nos brasileiros a impressionabilidade pelos movimentos elevados e pelas emoções generosas, o amor teórico da liberdade, a generosidade natural, a aptidão para aprender, a eloquência fácil. Se não encontrei neles algo da energia e tenacidade das raças do Norte, não me esqueço de que esta é uma distinção tão antiga quanto a que guardam entre si as próprias zonas temperada e tórrida. ${ }^{23}$
\end{abstract}

Toda essa junção entre descrição de hábitos, espécies vivas e recursos minerais presentes nas impressões deixadas insere-se na concepção humboldtiana de paisagem, na qual é possível a partir do microecossistema representar os fenômenos naturais e leis gerais que regem a totalidade cósmica.

Vejamos agora como essa visão operativa é perceptível nas técnicas de exploração das naturalistas viajantes, não querendo com isso menosprezar as suas capacidades criativas e inovadoras, porém, gostaríamos apenas de sinalizar para o fato delas estarem ligadas aos novos preceitos científicos que animavam o campo intelectual nos países do Norte (E.U.A., Inglaterra, França e Alemanha) e que eram discutidos e difundidos pelas suas mais prestigiadas instituições de ensino e pesquisa.

\title{
As viajantes naturalistas e suas impressões sobre o Brasil Oitocentista
}

Maria Graham (1785-1842), esteve no Brasil entre os anos de 1821 e 1825 em companhia do seu esposo, 0 capitão Thomas Graham, e assim como diversos outros viajantes, produziu um valioso relato de viagem no qual é possível entrevermos elementos da vida cotidiana e das riquezas naturais do Brasil e de seus habitantes. Seu relatório expedicionário foi publicado em Londres em 1824 e contém diversas informações com relação ao mercado de escravos, ao processo de Independência do Brasil, a vida social da população mais simples e abastada, além de conter descrições

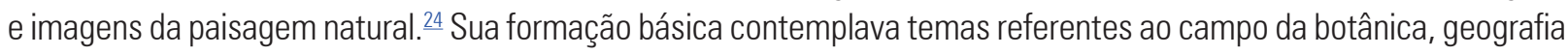
e história como apontam alguns dos estudiosos que analisaram sua vida e sua produção intelectual. $\underline{25}$

A sua viagem ao Brasil em 1821 tinha como objetivo defender os interesses britânicos na América do Sul em meio ao movimento de independência da tutela portuguesa - principal parceiro econômico e político da Inglaterra. Mostrou ao longo de seus relatos o forte engajamento nos assuntos referentes a política e um profundo conhecimento dos temas relacionados a administração pública, a economia e a cultura letrada. $\underline{26}$ Algumas das críticas estabelecidas pela viajante diz respeito aos interesses meramente econômicos da Inglaterra com relação as porções americanas. ${ }^{27}$ Além de suas andanças pelo território brasileiro e chileno, no ano de 1823 tornou-se preceptora de Maria da Glória, filha de D. Pedro. Foi também durante os seus últimos anos de estadia no Brasil que passou a produzir pranchas da flora brasileira e intensificou seu contato com outros cientistas europeus, especialmente William Hooker, professor de botânica da Universidade de Glasgow. ${ }^{28}$ Desse empreendimento resultou uma coleção com mais de 250 ilustrações. ${ }^{29}$ Além de suas contribuições para o campo da biologia, são valiosas as suas imagens da vida social brasileira, sobretudo das mulheres e escravizados. Segundo Marcelo Alves Cerdan (2003), nos relatos da inglesa é possível extrairmos 
informações com relação a alimentação, as vestimentas, as habitações, os aspectos morais, o sistema matrimonial e as técnicas de trabalhos dos escravizados brasileiros. ${ }^{30}$

Mesmo que tenha feito críticas com relação aos interesses britânicos no Brasil, como aponta Francine Medeiros e Maria Zubaran, "sob a influência da ideologia de gênero da classe média inglesa, Maria Graham julgou o comportamento das mulheres brasileiras através dos rígidos padrões de feminilidade vitorianos e reproduziu o discurso imperial associando as maneiras inglesas à superioridade cultural".$\underline{31}$

De acordo com Maria de Fátima Medeiros de Souza (2017), mesmo que os relatos escritos pela viajante estejam entre as principais referências para os estudos dos naturalistas exploradores do século XIX, suas obras pictóricas ainda não foram devidamente analisadas, 0 que nos proporcionaria ampliar nossos horizontes com relação a vida social brasileira. ${ }^{32}$

Ao longo dos anos em que esteve no Brasil, a viajante inglesa frequentou desde os salões luxuosos da capital federal até quilombos, florestas e fazendas especializadas na produção agrícola e que contavam com enorme plantel de escravos. Foi durante este mesmo período que realizou diversas coletas de plantas, que rapidamente foram enviadas a Europa e que foram utilizadas especialmente na produção de Flora Brasiliensis entre os anos de 1840 e $1906 . \underline{33}$ Outra personagem que contribuiu ativamente para a produção científica durante o século XIX e que teve o Brasil enquanto circuito de coleta de dados, foi Tereza da Baviera - figura ilustre do fin de siècle.

Therese Charlotte Marianne Auguste (1850-1925), também conhecida como Tereza Princesa da Baviera, nasceu em Munique e fazia parte da nobreza alemã e durante a sua maioridade empreendeu viajens exploratórias em diversos continentes. Desde muito cedo interessou-se pelos estudos da geografia, biologia e culturas não-europeias. ${ }^{34}$ Acredita-se que sua vinda à América esteja ligada ao projeto iniciado pelos seus patrícios Spix e Martius, dos quais certamente conhecia os trabalhos. Publicamente conhecida como cultora das ciências, foi agraciada em 1897 com o título de Doctor Philosophiæ Honoris Causa, sendo a primeira mulher a receber tal honraria. Tornou-se membro e colaborou ativamente como sócia de importantes instituições cientificas europeias, entre elas: Sociedade Geográfica de Munique e Real Academia de Ciências da Baviera, além de correspondente de instituições em Lisboa, Viena, Paris e Berlim.

Em 1888, juntamente de sua dama de companhia, um mordomo e um criado taxidermista veio conhecer os trópicos, visitando tribos indígenas, coletando plantas, animais e objetos etnográficos. Durante suas viagens carregou consigo sua máquina fotográfica, a fim de capturar com fidelidade as principais características dos locais visitados, procedimento e técnica inovadora para o período. Porém, a enorme paixão e devoção pela fotografia não fez com que abandonasse a técnica da pintura - posteriormente melhoradas por pintores profissionais e reproduzidas em seus trabalhos. Entre os quatro meses que passou pelo Brasil conheceu um total de 13 províncias, tendo como resultado a coleta de mais de 2.500 espécies animais, vegetais e objetos, além da produção de Meine Reise in den Brasilianischen Tropen ${ }^{35}$ em 1888 e publicada em 1897 em Berlim. Enquanto esteve no Brasil, especialmente durante sua passagem pela região amazônica, estabeleceu estreito intercambio com Emílio Goeldi no Pará e Orville Derby, americano radicado em São Paulo. Em um campo marcado pela forte presença masculina, a participação de mulheres como Teresa na produção da ciência sinaliza para uma tímida mudança nos comportamentos das sociedades ocidentais, em especial a europeia de fins do século XIX. $\stackrel{36}{\text { Afirma a própria Tereza: }}$

Foi, em primeiro lugar, a intenção de contribuir de modo complementar para a zoologia e a botânica que me levou a organizar os resultados da minha viagem relacionados a esses campos e a cogitar a sua publicação. Enquanto estava ocupada com esse trabalho, ocorreu a grande revolução política no Brasil, e também logo em seguida o nobre casal imperial daquele país foi levado para o repouso eterno. Agora, aquilo que eu havia visto e vivido na corte do Brasil pertencia a um período histórico encerrado, e muito daquilo ganhava em interesse pelo fato de que dali em diante não poderia mais ser observado. .37

Em sua obra é possível perceber o seu encantamento com a geografia americana e com a variedade de espécies encontradas nas matas virgens. Já em seu prefácio e ao longo de todos os seus relatos lamenta imensamente a escassez de estudos sobre a natureza do Brasil, o que segundo ela Ihe auxiliaria na composição e comparação de seus 
resultados. Em sua passagem pelo Espírito Santo visitou aldeias indígenas dos povos considerados como Botocudos e relatou muitos dos hábitos e modos de vidas dos ameríndios. Relatava ainda a existência entre nós de "índios civilizados" e "índios selvagens", além da diversidade de grupos. Afirmava que estes eram os povos que se encontravam na escala mais baixa do processo de civilização, especialmente por desconhecerem as vantagens dos usos das canoas para transporte e dos utensílios de barro para a atividades cotidianas. Com relação às suas características morais considerava que, "a sua índole é indolente, são famintos, inclinados a roubar e facilmente irritáveis, porém também podem ser bondosos, e se forem tratados com gentileza, pode-se esperar o mesmo deles". .38 Com relação a natureza brasileira é possível percebermos o deslumbramento no que diz respeito a diversidade de espécies da fauna e da flora, bem como na variedade de ecossistemas, povos e objetos típicos. Mostrou ainda deslumbramento pelas culturas nativas, porém, tomando por base as suas impressões é possível percebermos o olhar pejorativo com relação ao "Outro", classificado a partir dos padrões europeus como selvagens, civilizados ou em vias de civilizar-se ou desaparecer.

Vejamos agora um pouco da trajetória e das impressões deixadas por outra expedicionária europeia, Mariane North (1830-1890), que também esteve no Brasil em fins do século XIX. Nascida em Hastings, na Inglaterra, dedicou-se desde cedo a aprimorar suas habilidades de pintura. Após a morte de sua mãe, em 1855, passou a acompanhar o seu pai em viagens pela Europa, e com a morte do mesmo, em 1869, decidiu seguir seu projeto de pintar a fauna e a flora de países distantes. A partir de 1871 passou pelo Canadá, Estados Unidos e Jamaica. Passou ainda pelo Tenerife, Brasil, Japão, Bornéu, Singapura, Gales, Java, Ceilão e Índia. Em seu retorno a Grã-Bretanha exibiu muito de seus trabalhos em Londres, tendo oferecido muitas das espécies de sua coleção para o Royal Botanic Gardens em Kew. ${ }^{39}$ Por sugestão de Charles Darwin, a naturalista dirigiu-se para a Oceania em 1880 e retratou imagens da Austrália e da Nova Zelândia. Passou ainda pela África do Sul em 1883 e pelo Chile entre 1884-1885. Foi uma importante personagem para o campo da botânica, tendo contribuído ativamente com diversas instituições científicas europeias. $\stackrel{40}{-1}$

Em um interessante trabalho publicado em 2000 na revista Cadernos Pagu, John Dickenson analisou a contribuição de Marianne North, com suas pinturas durante a sua passagem pelo Brasil na segunda metade do século XIX, acerca da natureza brasileira. Este estudo buscou enquadrar o trabalho de North entre as produções dos viajantes-naturalistas do século XIX. Mesmo não tendo uma formação em história natural ou em qualquer uma das emergentes disciplinas a ela vinculadas, era uma conhecedora dos mais importantes trabalhos em História Natural. Dickenson apontou para a predominância de uma visão sexista, em que as produções femininas são vistas como obras "menores" frente àquelas produzidas pelos naturalistas-viajantes. A produção de North situa-se entre a arte e a botânica, com valiosas contribuições para ambos os campos. ${ }^{41}$ Nas palavras de Dickenson,

Seria fácil demais ver Marianne North meramente como uma pintora de flores exóticas, ou deixá-la de lado porque essas pinturas não são adequadas aos cânones científicos da arte botânica ou ao austero esteticismo contemporâneo das "flores como arte". É possível explorar seu papel como pioneira no retrato da natureza tropical ou, pelo menos, como uma historiadora da natureza e cientista de campo amadora. A totalidade de sua obra parece oferecer uma oportunidade de explorar não só o talento e engenho de uma artista viajante, mas também de buscar uma perspectiva de gênero em seu registro de lugares, pessoas e ambientes no apogeu do imperialismo. Certamente no caso de suas pinturas brasileiras há inúmeros temas a serem explorados. Mesmo no nível mais modesto, ela pode ser vista como uma pioneira na representação visual da flora do sudeste brasileiro. ${ }^{42}$

De acordo com Ana Lúcia Almeida Gazzola, Marianne North foi uma das viajantes que melhor conheceu o Brasil. Esteve aqui entre os anos de 1872 e 1873, tendo passado por cidades como Recife, Salvador, Rio de Janeiro, Petrópolis, Teresópolis, Juiz de Fora, Barbacena, Congonhas, Ouro Preto, Moro Velho, Caeté, Mariana, Curvelo, Cocais, Santa Luzia, Sabará e Lagoa Santa. Ainda de acordo com a pesquisadora, seu relato é carregado de uma fina ironia com os hábitos e costumes dos sujeitos do qual teve contato, bem como de duras críticas sobre pessoas com as quais conviveu, exceto de seus amigos aqui estabelecidos. ${ }^{43}$ De acordo com Gazzola, 
Embora expresse várias vezes seu agradecimento pela hospitalidade que recebe, inclusive de famílias desconhecidas em cujas casas solicitava hospedagem durante suas viagens, North não se cansa de apresentar comentários bastante agressivos. Refere-se, por exemplo, ao "desejo costumeiro [dos mineiros] de saberem o preço de tudo", considera vários de seus conhecidos "desprovidos de ideias", registra que "patriotas são raros no Brasil", menciona repetidamente a sujeira de casas e pessoas e representa de maneira grosseira e caricatural aspectos físicos e costumes locais. Sobre uma família que lhe oferece hospedagem, por exemplo, comenta que "teria feito fortuna em um parque de diversões"; cita a referência feita por uma inglesa a uma senhora conhecida como sendo "muito respeitável [...] para uma brasileira"; menciona a pouca curiosidade dos brasileiros pelas coisas do País; revolta-se com a impunidade dos criminosos e a falta de justiça. Mesmo ao elogiar, critica: uma horta bem cuidada é "um milagre de limpeza para o Brasil"; uma das casas que aluga é "limpa [...] considerando as pessoas que a cuidam"; a família que a hospeda gosta de música, mas "é uma plateia sem talento", e assim por diante. $\underline{\text { 44 }}$

0 que se pode concluir desses comentários é que as impressões da realidade do Brasil estavam fortemente marcadas pelos padrões comportamentais europeus, especialmente da sociedade vitoriana. Ana Lúcia Gazzola ainda defende que até mesmo nas descrições das paisagens rurais e urbanas é possível entrevermos a "ancoragem do olhar observador em sua própria cultura". ${ }^{5}$ É possível encontrarmos a dicotomia entre as belezas e riquezas da natureza e a miséria da humanidade. Dessa forma a autora defende que para North a Inglaterra não é apenas o ponto de partida da observação - local de fala - é também o ponto final - representação que a viajante faz dos países visitados -, como ponto de comparação.

Mesmo que seus trabalhos sejam marcados fortemente pelo interesse na representação da diversidade vegetal, são impressionantes e curiosas as imagens cotidianas pintadas por Mariane North. Sua viagem ao Brasil lhes rendeu cerca de 100 quadros, ou seja, 1/8 de sua coleção disponível em Kew. Como já salientado por John Dickenson, "um obstáculo considerável para tentar explorar a significação das pinturas de Marianne North é que a "arte botânica" está entre a arte e a botânica, e assim tem que satisfazer tanto ao gosto artístico quanto às normas científicas". .66

Nas imagens selecionadas, encontraremos como pano de fundo alguns dos elementos considerados "típicos" da vida brasílica em fins do oitocentos e que foram representados a partir do modelo paisagístico.

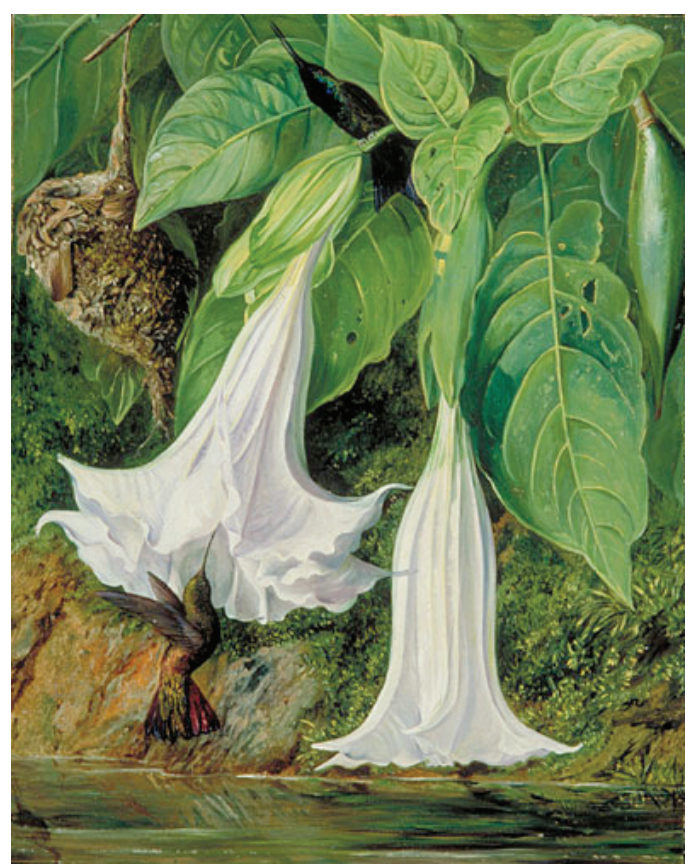

Figura 3. Flowers of Datura and Humming Birds, de Marianne North. Disponível em: https://www.kew.org/mng/gallery/047.html

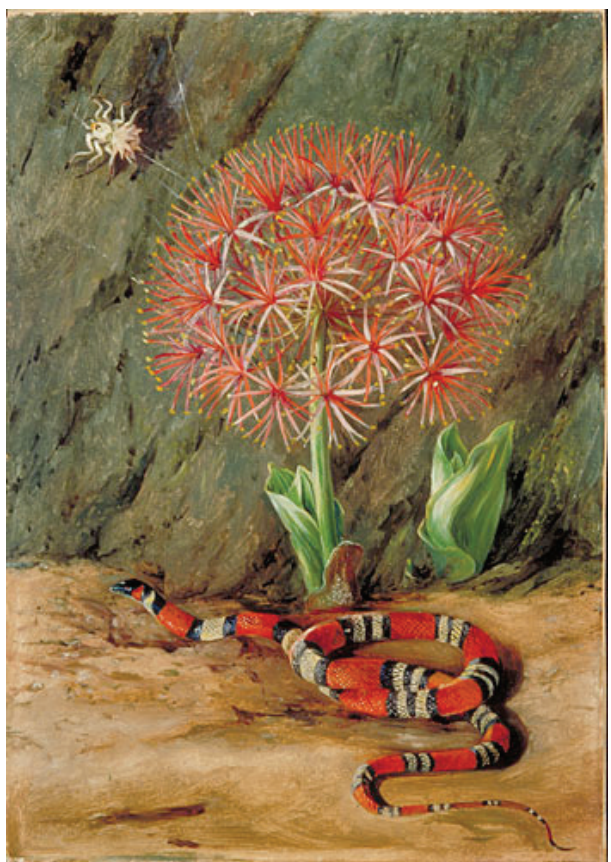

Figura 4. Flor Imperiale, Coral Snake and Spider, de Marianne North.

Disponível em: https://www.kew.org/mng/gallery/042.html 


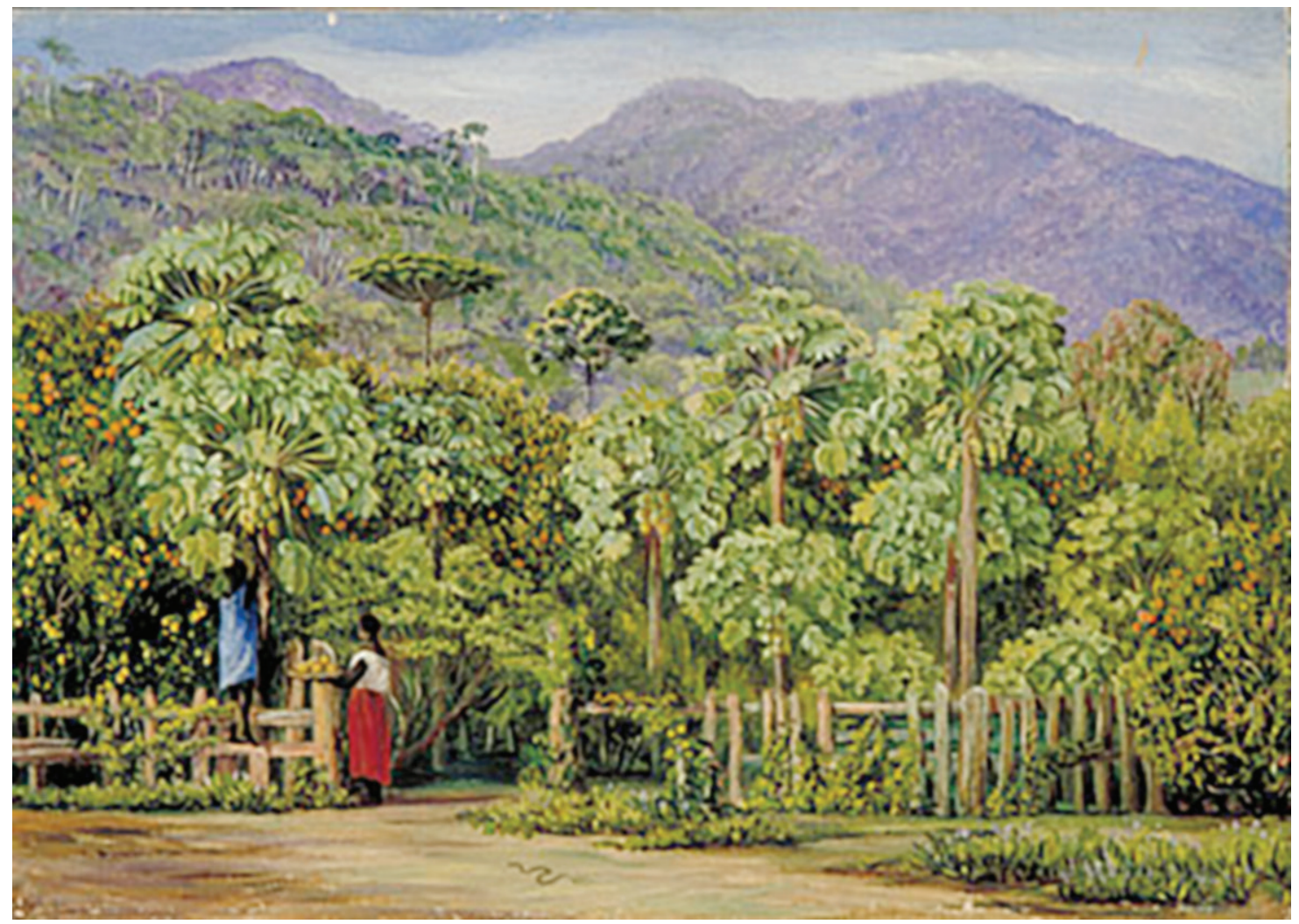

Figura 5. Pawpaw Trees at Gongo, de Marianne North. Disponível em: https://www.kew.org/mng/gallery/091.html

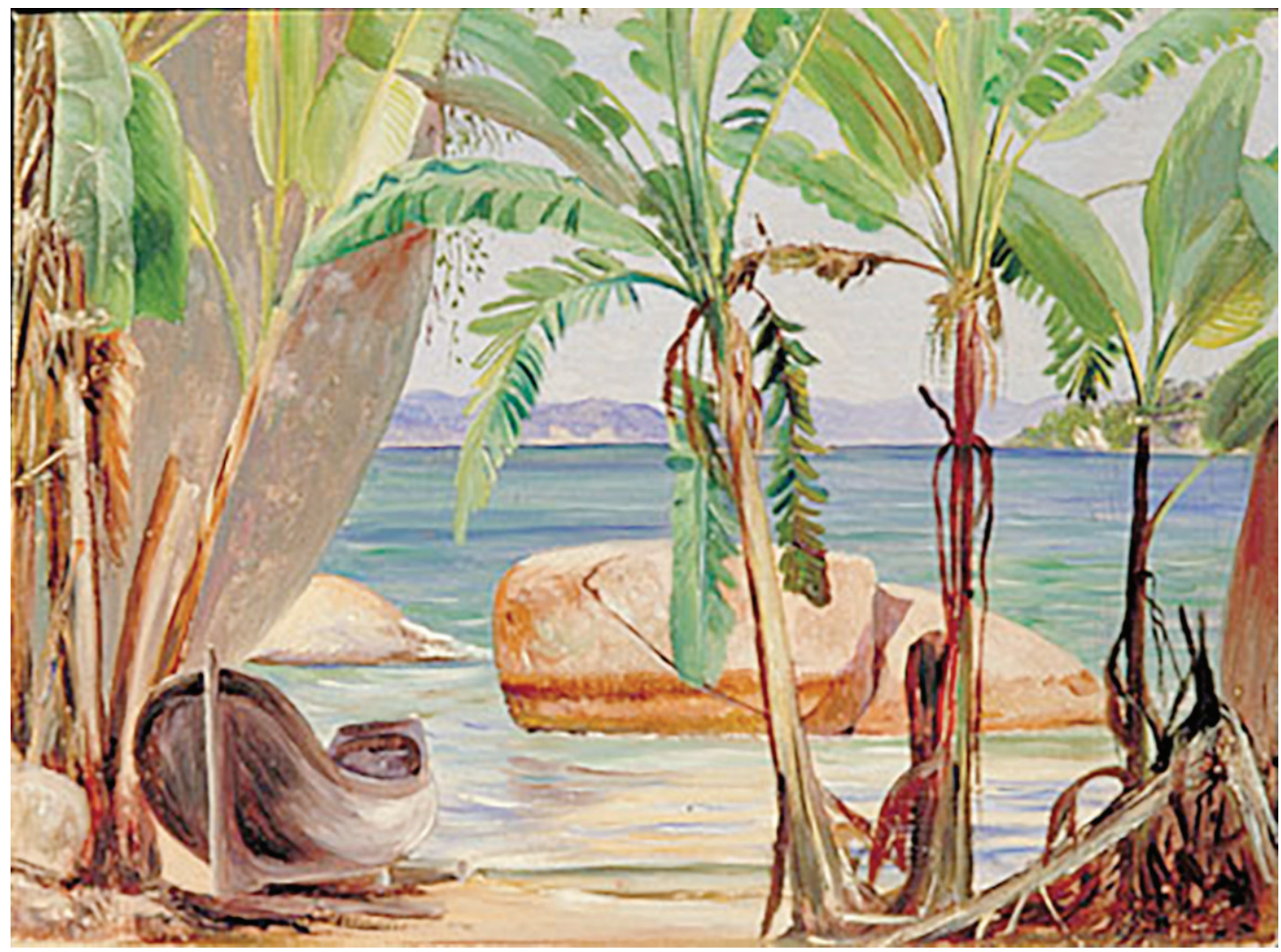

Figura 6. Bananas and Rocks at Paquita, de Marianne North. Disponível em: https://www.kew.org/mng/gallery/150.html 
Um dos aspectos mais relevantes da produção pictórica de Marianne North é seu hibridismo. Mesmo que as plantas estejam no centro de suas imagens, e possível percebermos em suas representações uma série de outros elementos que compõe o meio no qual seu objeto encontra-se disposto. 47

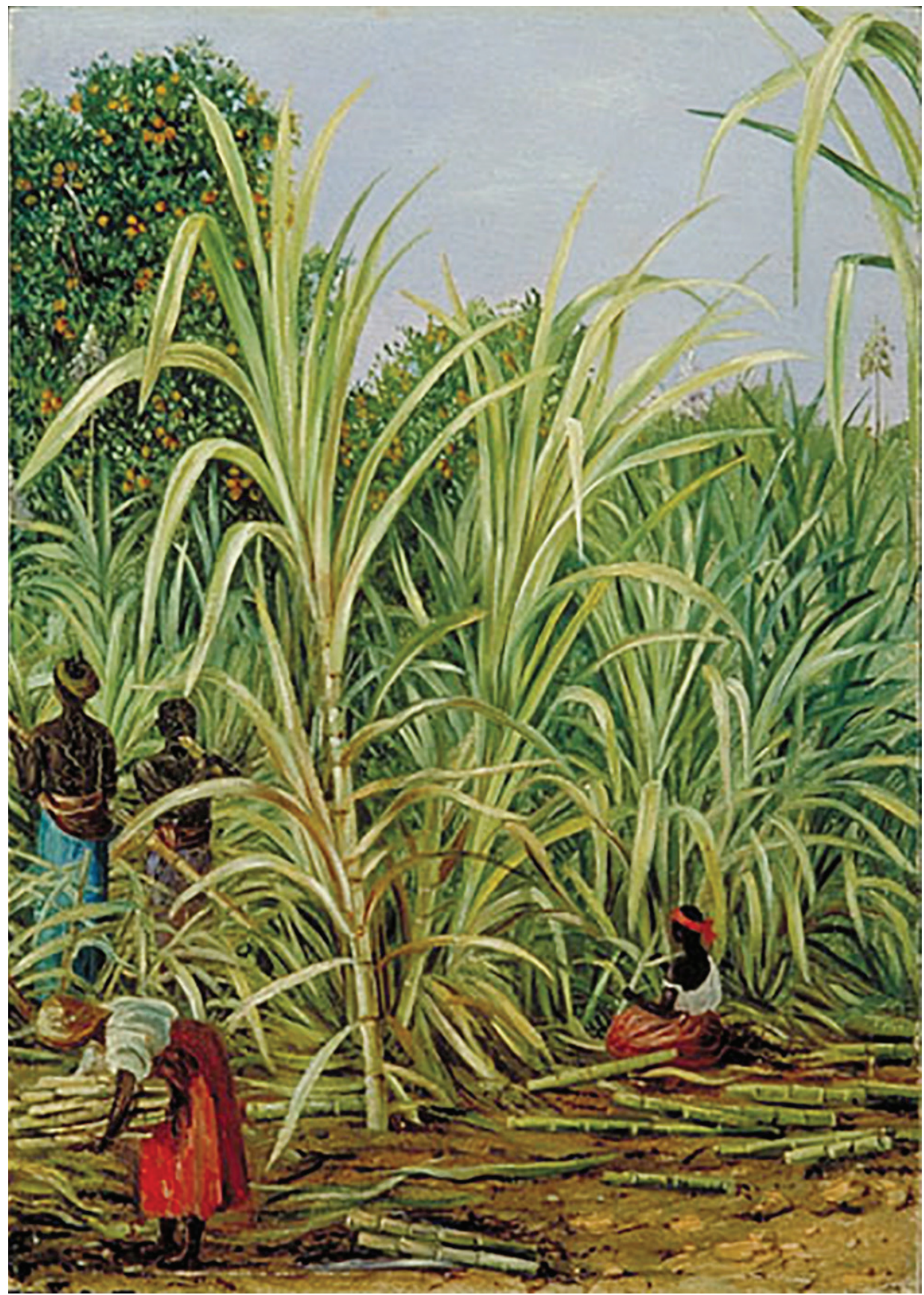

Figura 7. Harvesting the Sugar-Cane in Minas Gerais, de Marianne North. Disponível em: https://www.kew.org/mng/gallerv/045.html

Os elementos que aqui estamos caracterizando como "típicos" do Brasil são: a diversidade da vida animal e exuberância vegetal, bem como a abundância de recursos hídricos; o meio de transporte artesanal fluvial; e, a utilização da mão-de-obra escrava. Perceba-se que nas imagens selecionadas é possível vermos não apenas elementos da fauna e da flora, como os habitantes do Brasil - especialmente os escravizados - em suas atividades cotidianas, tais como o trabalho no campo. 
Mesmo que seu status como cientista seja problemático, pode-se dizer que, dada sua confessada falta de educação formal, não tinha treinamento científico, porém, à maneira das mulheres de sua classe e época, adquiriu um conhecimento operativo da história natural por seus contatos sociais - William e Joseph Hooker e Charles Darwin na Inglaterra. No Brasil, entrou em contato com M. Bourget, um dos companheiros de Agassiz; com o Diretor do Jardim Botânico no Rio; com um naturalista local em Barbacena; com o naturalista dinamarquês P. W. Lund em Lagoa Santa; e com um companheiro de Humboldt em Petrópolis. $\underline{48}$

A imagem do Brasil e de seu povo que chega a partir das descrições e pinturas feitas por Mariane North é de uma natureza rica, farta e de beleza ímpar, que contrasta com um povo selvagem, de hábitos grosseiros e de gestos hostis - exceto pela hospitalidade recebida por alguns mineradores e estrangeiros que habitavam o território brasileiro, em especial na província mineira, localidade onde passou cerca de oito meses, maior parte do tempo em que esteve no Brasil.

Como vimos, durante o século XIX, pluralizou-se as representações acerca do Brasil e de seu povo, ao passo que as ciências naturais se institucionalizavam no país. Foi durante este mesmo período que uma série de naturalistas, exploradores, diletantes e artísticas afluíram para estas partes do mundo, a fim de ampliares os conhecimentos acerca da natureza americana, de seus hábitos e costumes, além de seu povo. Nesse mesmo momento aumentou 0 número de naturalistas mulheres que tiveram o Brasil como destino. Exemplos como 0 da inglesa Maria Graham, da estadunidense Cary Agassis, da alemã Tereza e da também inglesa Marianne demonstram a importância desta parte no mundo no circuito internacional de produção de conhecimento e a tímida mudança na mentalidade ocidental acerca da relevância das mulheres na produção de ciência.

\section{Entre arte e ciência: a natureza brasileira pintada pelas viajantes naturalistas inglesas}

Em uma entrevista concedida à IHU-On-line (revista do Instituto Humanitas Unisinos), Lorelai Kury, afirmou que uma das principais marcas das representações iconográficas produzidas pelos naturalistas europeus que estiveram no Brasil durante o século XIX, é o "pitoresco", marcado sobretudo pelo neoclassicismo. $\underline{49}$

Como bem nos informou Dennys Silva-Reis, a imagem é considerada um artefato cultural e "[...] pode ser utilizada como fonte história, pois tem o poder de representar, reproduzir ou fazer analogia ao imaginário coletivo ou à mentalidade de determinada época ou sociedade". $\underline{50}$ Ao analisar o desenvolvimento do campo de estudo Iconografia, surgido na Grécia, e readaptado ao longo das gerações subsequentes, o autor realizou uma distinção entre iconografia (campo de estudo) e iconologia (abordagem de interpretação das imagens), estando ambas associadas ao estudo minucioso das imagens - portadoras, assim como os textos, de linguagens próprias. Defendeu também que, as imagens são formas de pensamentos e podem conter mais significados para uma sociedade do que para outra.

Peter Burke, importante historiador inglês, ao longo de seu trabalho Testemunha ocular: História e imagens, chamou atenção para o equívoco de tratar iconografia e iconologia como sinônimos..$^{51} \mathrm{~A}$ iconologia é um subcampo dentro da iconografia e caracteriza-se pelo processo interpretativa das imagens. 0 método iconológico compreende uma produção imagética a partir de três etapas: a primeira etapa é precisamente o registro pré-iconográfico, onde são levados em conta os temas disponíveis e as técnicas de produção; a segunda etapa trata-se do processo da descrição abstrata e interpretação dos elementos internos e externos das imagens (símbolos, personagens, locais, cores, disposições, materiais etc.); a terceira etapa concentra-se na investigação acerca dos objetivos e intencionalidades geradoras (como, onde e por que a imagem foi gerada). Um dos pioneiros e principais expoentes desse método foi Erwin Panofsky, famoso crítico e historiador da arte alemã. Para este autor, iconografia significa o estudo dos temas ou assunto, enquanto iconologia significaria 0 estudo do significado. $\underline{52}$ 
Dada essa a distinção preliminar entre estes dois conceitos, nos debruçaremos no estudo iconológico das imagens, sem perder de vista também os aspectos iconográficos mais relevantes acerca das pinturas selecionadas.

0 livro Journal of a voyage to Brazil, and residence there during part of the years 1821, 1822, 1823 de Marian Graham foi publicado em 1824 em Londres, e está entre as obras naturalistas mais importantes da primeira metade do século XIX, em especial, do período de Independência. A obra é um valioso relato de viagem, escrito na primeira pessoa, e que narra com precisão de dias e locais, as cenas presenciadas pela exploradora. Contém um total de 376 páginas e 21 imagens. Esse está dividido em quatro partes (Introdução, $1^{\text {a }}$ viagem, $2^{a}$ viagem e apêndices) e descreve os dois momentos em que esteve no Brasil.

A maior parte das imagens contidas neste trabalho, apresentam a paisagens da natureza brasileira, as cidades visitadas vistas de longe e cenas do cotidiano, especialmente, do trabalho escravo. Na tabela a seguir, agrupamos as imagens a partir de seus temas principais:

\begin{tabular}{|c|c|}
\hline Tema & Quantidade de ocorrências \\
\hline Cotidiano da escravidão & 7 \\
\hline Panorama das cidades visitadas & 6 \\
\hline Autorretrato & 1 \\
\hline Elementos da flora local & 6 \\
\hline Outros & 1 \\
\hline Total & 21 \\
\hline
\end{tabular}

Do total de imagens arroladas, optamos em analisar mais detidamente duas delas, a fim de demonstrarmos a utilização do modelo paisagístico na representação do cotidiano brasileiro. A partir da tabela supracitada, é possível perceber que, o tema mais recorrente nas representações iconográficas contidas no Journal... foi o cotidiano dos povos escravizados, seguida pela representação panorâmica dos locais visitados e dos elementos da flora local.

Na primeira imagem, vemos uma cena do cotidiano dos escravizados que, habitavam e trabalhavam na província do Pernambuco. Com relação aos condicionantes pré-iconográficos, temos a colonização portuguesa e a escravidão como principais bastiões do poder brasileiro, e em relação ao campo da arte, temos a predominância do já mencionado neoclassicismo, sobretudo na Europa Ocidental e entre seus admiradores. A pintura mostra a brutalidade praticadas pelos "senhores", na sua totalidade homens brancos e com idade adulta, executadas a luz do dia, em uma localidade destinada ao hediondo comércio de pessoas. Dela é possível extrairmos uma série de dados. Vejamos: se somados é possível encontrarmos mais de 50 personagens, sendo em sua maioria negros; o que está no centro da imagem é o comércio dos escravos; apenas uma personagem negra está desenvolvendo uma atividade comercial, a de vendedora, e parece horrorizar-se com a cena; a vendedora parece lançar uma fruta à única "criança" presente na imagem e que aparece no canto inferior direito, agonizando no chão na tentativa de alcançar o alimento; todos os brancos aparecem vestidos, armados e até mesmo montado a cavalo; ao centro encontra-se o negociante; ao fundo é possível ver uma série de curiosos alocados na igreja; da rua à calçada é possível assistirmos a cenas de violência física. As intenções parece ser 0 horror e a brutalidade do comércio de escravos e a dominação do homem branco com relação aos negros escravizados.

Vale salientar que, não desejamos realizar aqui apenas uma descrição das imagens, gostaríamos de efetuar uma análise mais minuciosa de seus aspectos e pôr em relevo os elementos considerados típicos da vida nos trópicos: 0 trabalho escravo (adulto e infantil) de homens e mulheres e a brutalidade praticada pelos brancos oitocentistas. 


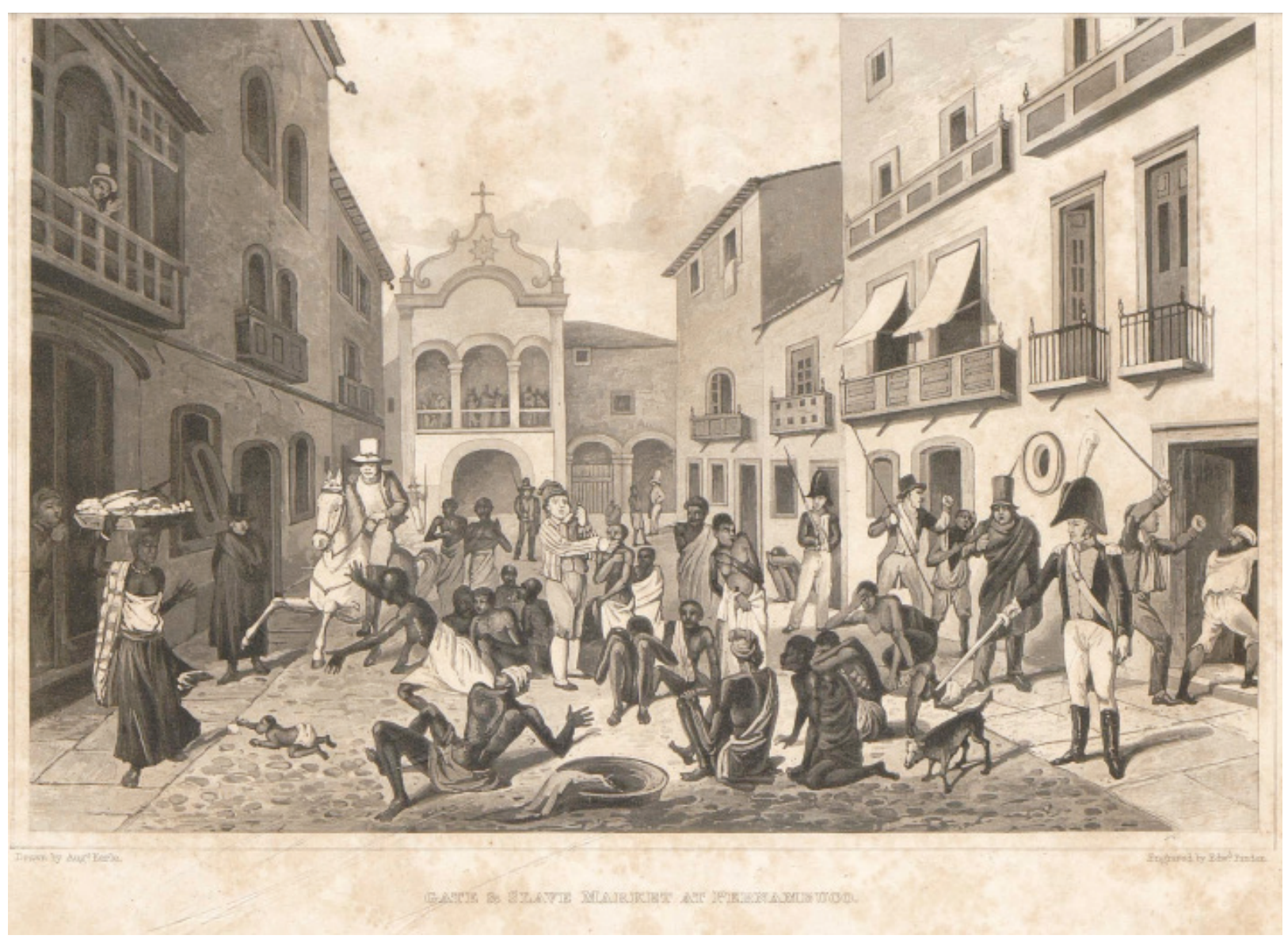

Figura 8: Gate \& Slave market at Pernambuco. Pintado por Augusto Earle e gravado por Eduardo Finden. In.: GRAHAM, Maria. Jornaul of a Voyage to Brazil, and residence there, during part of the years 1821, 1822, 1823. Londres: Logman, 1824, p. 107.

Na segunda imagem, vemos a representação da natureza vegetal e ao fundo a representação da urbe.$\underline{53}$ Nota-se que, assim como na análise feita com relação ao trabalho de Marianne North por parte de Ana Lúcia Gazzolla, é possível percebermos a dicotomia entre a riqueza e beleza natural e a miséria da humanidade. Com relação aos elementos pré-iconográficos, temos os mesmos condicionantes da primeira. A pintura representa a vista de São Cristóvão, bairro típico da cidade do Rio de Janeiro, então capital do Império. Com relação aos aspectos alegóricos da segunda, vemos que o objeto central é o bairro e seu entorno, visto de um de seus caminhos. É possível vermos o seu arco central, e uma imponente construção, cercados de uma natureza exuberante e diversificada. Na imagem ainda aparece um escravo, de pés descalços, levemente desnudo, empunhado com uma haste de madeira e carregando sob sua cabeça um objeto não identificado. 0 objetivo central desta representação parece ser a beleza da localidade e da geografia circunvizinha. 


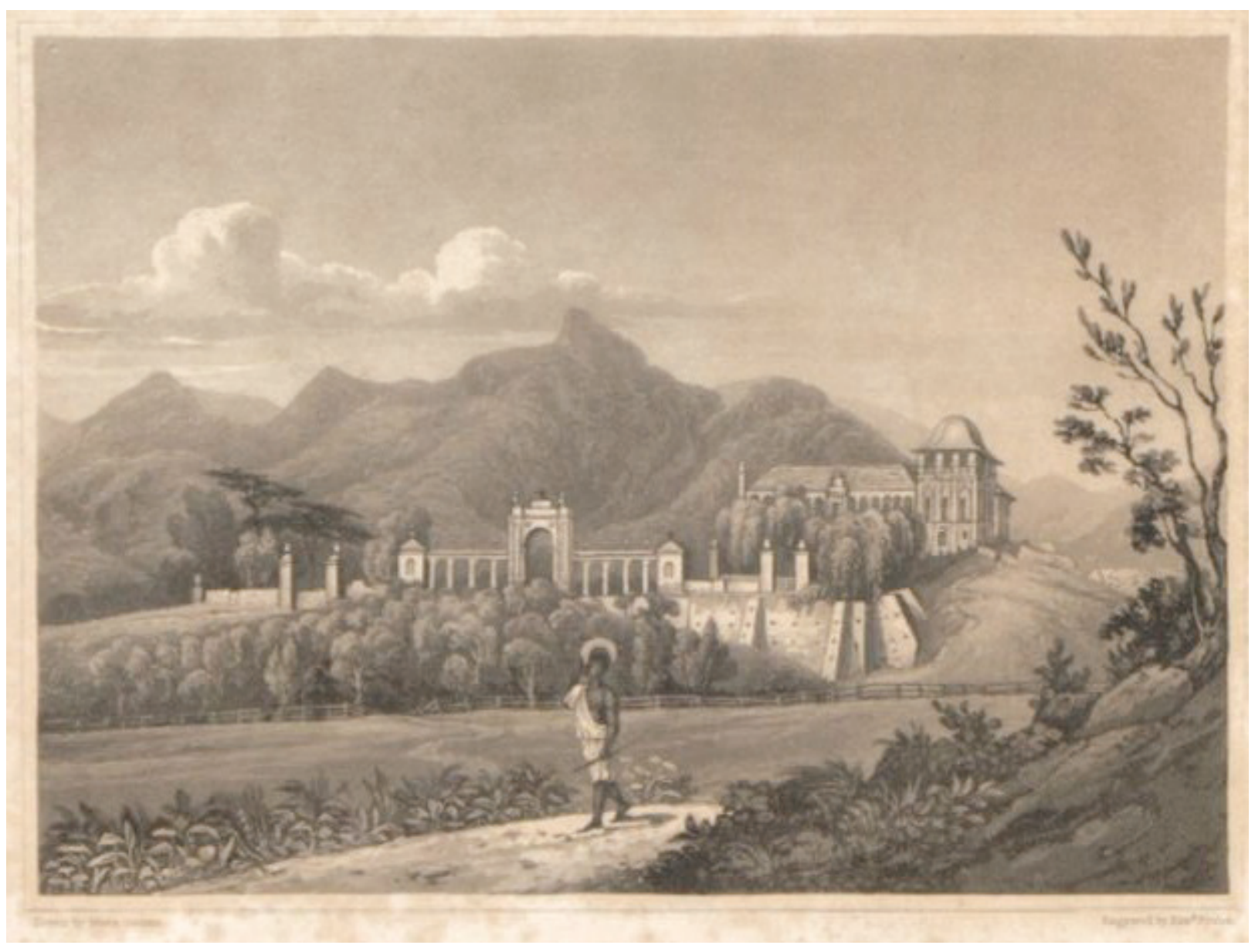

Figura 9: San Cristovão. Desenho de Maria Graham e gravação de Eduardo Finden. In.: GRAHAM, Maria. Jornaul of a Voyage to Brazil, and residence there, during part of the years 1821, 1822, 1823. Londres: Logman, 1824, p. 247.

0 deslumbramento pelos elementos da flora brasileira e o horror causado pela escravidão, parece estar presente nas imagens selecionadas por Maria Graham para representar o Brasil para os seus patrícios. Vejamos agora com a modelo paisagístico auxiliou a inglesa Marianne North em sua representação do Brasil.

De um total de 181 fotos analisadas, disponíveis no site de vendas do Royal Botanic Garden, é possível encontrar 65 imagens referentes ao Brasil, ou seja, 35,9\% do catálogo é composto por representações da flora brasileira.

Na imagem a seguir, vemos uma representação da vista de Morro Velho, localidade onde Marianne residiu por algum tempo em sua passagem pela província de Minas Gerais. 


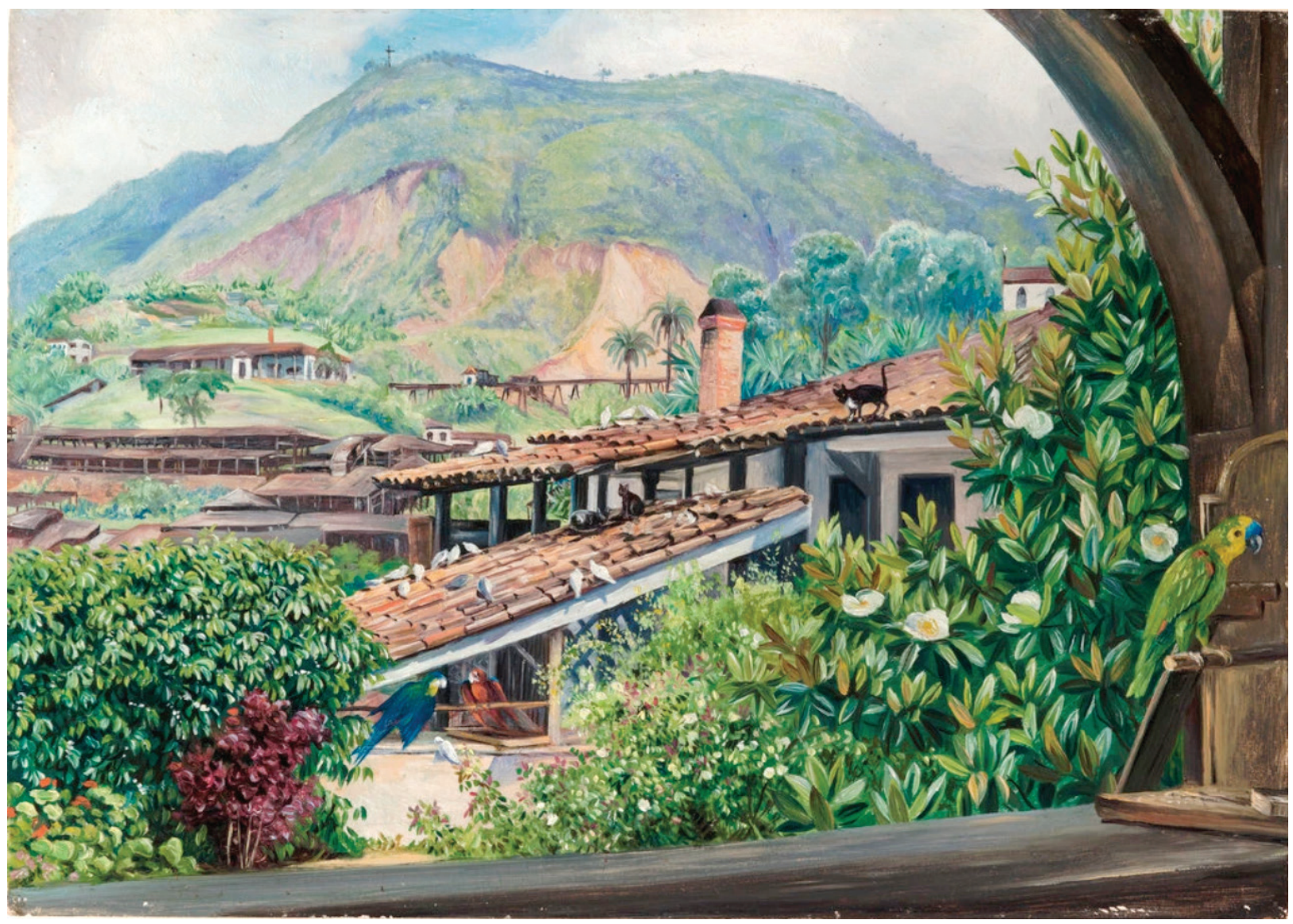

Figura 10: Vista do antigo caminho do ouro de uma varanda em Morro Velho, Brasil. Pintada por Marianne North.

Disponível em: https://prints.kew.org/products/95-view-of-the-old-gold-works-from-the-verandah-at-morro-velho-brazil-1880-mn-095.

Acessado às 14h:06 do dia 08/06/2019.

Nessa próxima imagem de Marianne North, vemos a representação da avenida de Palmeiras, localizada no Jardim Botânico do Rio de Janeiro, planta, introduzida no Brasil a partir de 1809, logo após a criação do espaço para atender à Família Real. ${ }^{54}$ Nas imagens selecionadas na sessão acima e na seguinte, encontramos a representação da escravidão como um elemento típico da vida nos trópicos. Em nenhum momento são questionadas as bases éticas e morais para a persistência, ainda em fins do século XIX, do hediondo sistema de produção escravista. De acordo com Ana Lúcia Gazzolla,

[...] Ao se referir aos negros, ela não esconde seu preconceito: as descrições os reduzem ao grotesco, ao ridículo ou ao pitoresco. Eles são "figuras estranhas, enormes, espalhafatosas", são preguiçosos e sorrateiros, e bastaria tê-los como empregados para perceber que os que os defendem estão equivocados. Em nenhum momento, ao abordar a questão da escravidão, Marianne contextualiza o comportamento dos negros. O que fica implícito é uma visão negativa dessa raça, sem uma avaliação das determinantes culturais que explicam as estratégias de sobrevivência utilizadas. Os elogios à "branda forma" que toma a escravidão no Brasil e as frequentes referências à alegria e ao contentamento dos escravos não convencem, pois Marianne se trai ao afirmar que esses são "tão mimados como nós mimamos nossos animais de estimação"! No retrato do outro, seja ele o negro ou o brasileiro, a autora opera por generalização e homogeneização, reduzindo a alteridade a um sistema fixo de diferenças em que a superioridade da cultura de referência fica assegurada..$^{\frac{55}{1}}$ 


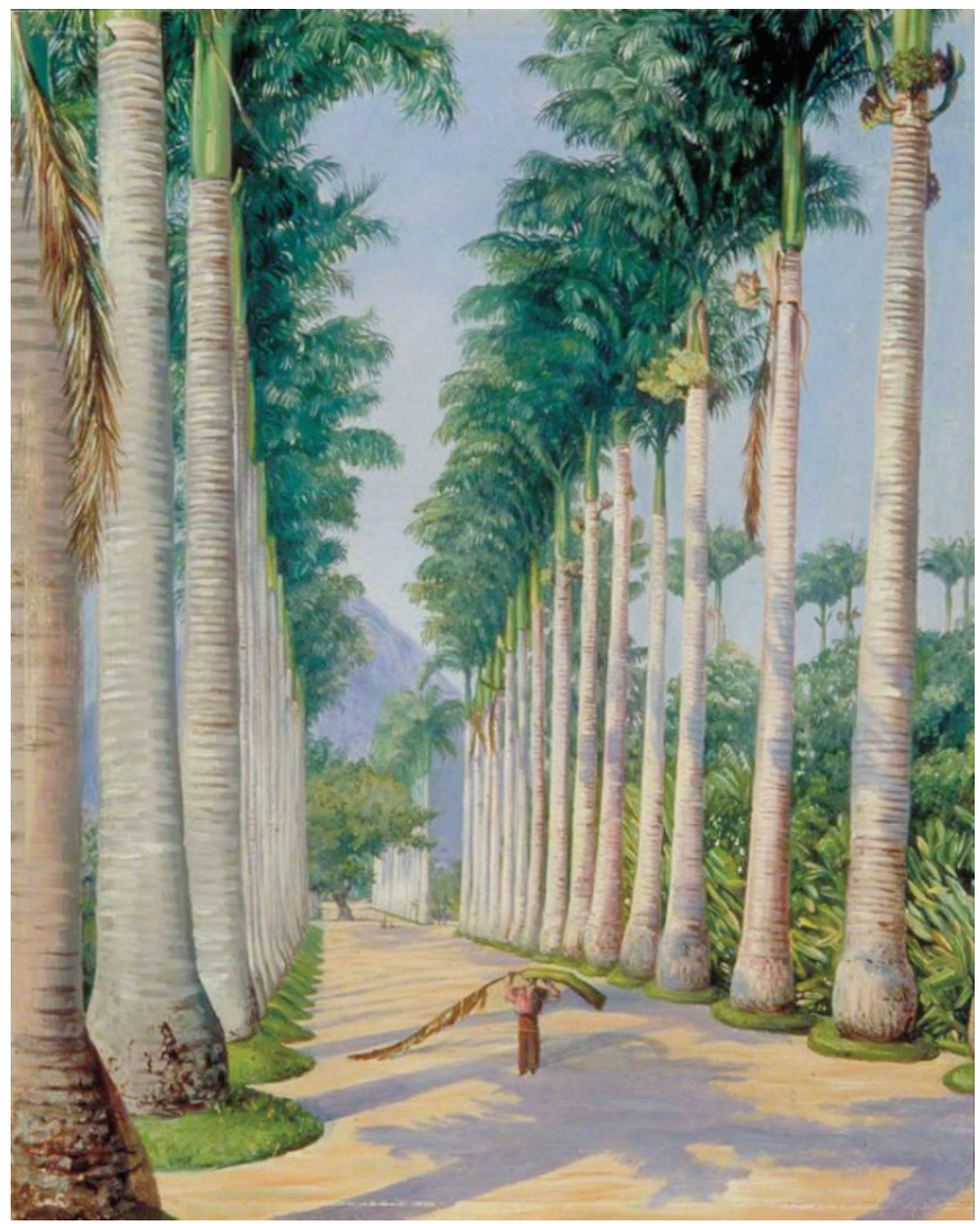

Figura 11: Avenida de Palmas Reais em Botafogo, Brasil. Pintada por Marianne North (1880). Disponível em: https://danieldelacalle.com/No-rth-Brasil. Acessado às $14 \mathrm{~h}: 26$ do dia 08/06/2019.

Com relação à representação do cotidiano brasileiro, diferente de sua predecessora, Marianne North não usou de seu relato para levantar qualquer denúncia à brutalidade da escravidão, tendo antes representado os escravizados como elementos típicos dos espaços observados. Nota-se que em todas as suas imagens onde aparece o trabalho servil, os trabalhadores estão desempenhando as suas atividades diárias e não é possível perceber nenhuma indignação com relação à ilegitimidade do trabalho escravo. Dessa forma, ao longo de todo o seu relato escrito e produção iconográfica, a escravidão não adquire o papel central, sendo, antes, visto como algo próprio daquela natureza pujante.

\section{Considerações finais}

As viagens naturalistas estiveram diretamente ligadas ao processo de institucionalização das ciências no Brasil. 0 processo de colaboracionismo exercido entre estrangeiros, sobretudo europeus durante o século XIX foi importante na construção da nação brasileira e suas instituições seguiram modelos, sobretudo francês e alemão de fazer "ciência". 0 apoio fornecido pelo governo imperial, bem como o financiamento de diversas comissões responsáveis pela escru- 
tinização do território foram fundamentais para o seu conhecimento e a delimitação de suas fronteiras, tanto no que concerne aos estados locais, quanto com as nações circunvizinhas. 0 modelo preconizado parece ter sido aquele arquitetado e defendido por Alexander von Humboldt de capturar a natureza e a vida com base na representação paisagística. A coleta de espécies museológicas, as produções iconográficas e textuais parecem ter sido as principais formas de representar o todo que existia em cada local. A busca pelo "típico" e sua representação a partir da "paisagem" foram marcas de um período pontuado pelos anseios racionalistas de compreensão do real a partir do que é natural, sem, no entanto, abandonar muitos dos anseios que eram também compartilhados pelos românticos.

A ciência das viagens bem como os diversos dilemas, deleites e desdobramentos continuam a interessar uma série de pesquisadores que veem nos relatos produzidos, nas representações iconográficas ou nos materiais coletados não apenas o Brasil, mas as expectativas destes estrangeiros, aqui em especial os europeus que passaram pelo país durante 0 século XIX.

Com relação a análise iconográfica entre os trabalhos das inglesas Maria Graham e Marianne North, percebemos que seus principais objetos eram a diversidade e a pujança dos recursos naturais brasileiros. Porém, com relação a análise iconológica, percebemos que em Maria Graham é possível encontrarmos uma série de temas centrais, estando a escravidão entre os principais assuntos abordados. Já com relação a análise iconológica das pinturas selecionadas de Marianne North, percebemos o seu forte engajamento em representar a diversidade das espécies vivas observadas nos trópicos, enquanto a escravidão Ihes aparece como um dos elementos típicos da paisagem brasileira.

Viajantes como Carl Friedrich Philipp von Martiuns, Johann Baptist von Spix, Alexander von Humboldt, Geoffroy Auguste de Saint-Hilaire, Louis Agassiz, Elizabeth Cary Agassiz, Maria Graham, Charles Darwin, Marianne North, Teresa da Baviera e tantos outros, deixaram valiosos indícios acerca do nosso passado social, assim como descrições da diversidade de elementos da fauna, da flora e do reino mineral. Os trabalhos historiográficos, sobretudo aqueles produzidos pela História das ciências no Brasil nos possibilitam analisar de forma mais crítica como se deu a construção de tais narrativas e quais são os seus limites e suas potencialidades para uma melhor compreensão do território no qual estamos situados e o mundo em que vivemos. Esperamos que esse trabalho possa estimular novas discussões em torno da participação das mulheres, em especial, das viajantes naturalistas, na produção das ciências durante o século XIX.

\section{Notas e referências bibliográficas}

Raick de Jesus Souza é mestre em História das Ciências e da Saúde pelo Programa de Pós-graduação em História das Ciências e da Saúde da Casa de Oswaldo Cruz/FIOCRUZ (2019); graduado em Licenciatura Plena pela Universidade Estadual da Bahia - UESB (2016). E-mail: raickdjs@hotmail.com

1 Esta investigação começou a ser desenvolvida durante a disciplina História das Ciências no Brasil no Programa de Pós-Graduação em História das Ciências e da Saúde pela Casa de Oswaldo Cruz/FIOCRUZ, na coordenação dos professores Flávio Coelho Edler, Carlos Eduardo Freire Estellita-Lins e Juliana Manzoni Cavalcanti e continuou a ser desenvolvida mesmo após o fim da disciplina, porém, de forma independente.

2 Cf. OLIVEIRA, Ana Rosa de. "0 Jardim Botânico do Rio de Janeiro e as paisagens da corte". In.: Lorelai Kury, Heloisa Gesteira (orgs). Ensaios de história das ciências no Brasil: das Luzes à nação independente. Rio de Janeiro: EdUERJ, 2012, p. 66.

3 Idem, p. 67.

4 Cf. BELLUZZO, Ana Maria. A proposto d'0 Brasil dos Viajantes. São Paulo: Revista da USP, vol. 30, p. 8-19, 1996, p. 18.

5 Cf. DOMINGUES, Heloisa Bertol. As ciências naturais e a construção da nação brasileira. In.: Revista de História. São Paulo, n. 135, p. 41-59, 1996 e A Sociedade Auxiliadora da Industria Nacional e as Ciências Naturais no Brasil. In.: DANTES, MAM (org). Espaços da Ciência no Brasil: 1800-1930. Rio de Janeiro: Editora Fiocruz, 2001, p. 83-110.

6 BELLUZZO, Ana Maria. 0 viajante e a paisagem brasileira. Revista Porto Arte. n. 25, v. 15, nov/2008. p. 41-57.

7 Cf. LEITE, Miriam Lifchitz Moreira. Naturalistas viajantes. In.: História, Ciências, Saúde - Manguinhos. Ano.1, v. 2, p. 7-19, 1995, p. 7.

8 SCHWARTZMAN, Simon. Formação da comunidade científica no Brasil. São Paulo: Ed. Nacional; Rio de Janeiro: Financiadora de Estudos e Projetos, 1979.

9 SCHWARTZMAN, op. cit., p. 53.

10 Idem, p. 58. 
11 LOPES, Maria Margaret. 0 início do movimento dos museus no Brasil. In.: O Brasil descobre a pesquisa científica: os museus e as ciências naturais no século XIX. São Paulo: HUCITEC, 1997, p. 151-221.

12 STEPAN, Nancy Leys. Going to the tropics. In.: Picturing Tropical Nature. Londres: Reaktions Books, 2001, p. 31-56.

13 STEPAN, 2001, op. cit., p. 31-32.

14 KURY, Lorelai Brilhante. "Viajantes-naturalistas no Brasil oitocentista: experiência, relato e imagem". In.: História, Ciência, Saúde - Manguinhos. Vol. VIII. Rio de Janeiro: 2001, 863-880.

15 KURY, 2001, op. cit., p. 864.

16 Idem, p. 865.

17 Idem, p. 869.

18 CORRÊA NETO, YImar. Louis Choris (1795-1825). n.120, Paraná: Revista Cremesc, 2014, p. 18-19.

19 KURY, 2001, op. cit., p. 870 .

20 Idem, 870

21 Idem, 879

22 AGASSIZ, Jean Louis Rodolph. Viagem ao Brasil 1865-1866. Luís Agassiz e Elizabeth Cary Agassiz ; tradução e notas de Edgar Süssekind de Mendonça.Brasília: Senado Federal, Conselho Editorial, 2000.

23 AGASSIZ, 2000, op. cit., p. 470.

24 Cf. LEME, Camila Assis; CAMPOI, Isabela Candeloro. Sob o olhar de uma estrangeira: Gênero e Independência do Brasil no diário de Maria Graham. Campo Mourão: VIII EPCT, 2013 e SILVA, Isadora Eckardt da; GOMES, Gina Maria de Oliveira. O subjetivismo na narrativa de viagem de Maria Graham. Porto Alegre: UFRGS, 2005

25 GONÇALVES, Margareth de Almeida. Subjetividade e viagem em Maria Graham. Londrina: ANPUH, 2005.

26 SILVA, Isadora Eckardt. O viés político e histórico de Maria Graham em Diário de uma viagem ao Brasil. Dissertação (Mestrado em Teoria e História Literária). Campinas: Unicamp, 2009.

27 CAMPOS, Maria de Fátima Hanaque. Relatos de viagem e a obra multifacetada de Maria Graham. Feira de Santana: Sitientibus, 2009.

28 CAMPOS, 2009, op. cit., p. 109.

29 Cf. PEIXOTO, Ariane Luna; FIGUEIRAS, Tarciso de Sousa. Maria Graham: Anotações sobre a flora brasileira. Rio de Janeiro: Acta botânica brasileira, 2008.

30 CERDAN, Marcelo Alves. Maria Graham e a escravidão no Brasil: Entre o olhar e o bico da pena e os leitores do diário de uma viajante inglesa do século XIX. Campinas: Unicamp, 2003.

31 MEDEIROS, Francine Castoldi; ZUBARAN, Maria Angélica. Narrativas de viagem de Maria Graham: Representações de alteridade e produção de identidades no Brasil oitocentista. Cachoeira do Sul: ULBRA, 2003, p. 157.

32 SOUZA, Maria de Fátima Medeiros de. Arte e ciência na obra de Maria Graham: Estudo da documentação científica do século XIX. Campinas: $26^{\circ}$ Encontro da Associação Nacional dos Pesquisadores em Artes Plásticas, 2017.

33 A Flora brasiliensis foi produzida entre 1840 e 1906 pelos editores Carl Friedrich Philipp von Martius, August Wilhelm Eichler e Ignatz Urban, com a participação de 65 especialistas de vários países. Contém tratamentos taxonômicos de 22.767 espécies, a maioria de angiospermas brasileiras, reunidos em 15 volumes, divididos em 40 partes, com um total de 10.367 páginas. Para melhores informações e consulta deste material, favor ver: http:// florabrasiliensis.cria.org.br/index.

34 BENTIVOGLIO, Júlio; SILVA, Levy Soares da. Tereza da Baviera: um breve perfil biográfico. In.: BAVIERA, Tereza da. Viagem pelo Espírito Santo (1888): Viagem pelos trópicos brasileiros. Tradução e notas de Sara Baldus; organização e notas de Júlio Bentivoglio. Vitória: Arquivo Público do Estado do Espírito Santo, 2013, p. 19.

35 Minha viagem aos trópicos do Brasil.

36 LEITE, Miriam Lifchitz Moreira. Mulheres viajantes no século XIX. In.: Cadernos Pagu. n. 15, p. 129-143, 2000. p. 134.

37 ALCÂNTARA, Lúcio. Breve nota sobre a passagem de Tereza Princesa da Baviera pelo Ceará. Fortaleza: Revista do Instituto do Ceará, 2014, p. 119.

38 BAVIERA, 2013, op. cit., p. 40.

39 Os Kew Gardens, como em geral são conhecidos, constituem um grande complexo de jardins, arboretos e estufas situados num vasto parque localizado entre Kew e Richmond upon Thames, na periferia sudoeste de Londres. São considerados os mais extensos, antigos e prestigiados Jardins Botânicos do mundo.

40 Cf. CARROLL, Khadija von Zinnenburg. NonWest by North. Abingdon: Third Text, 2018.

41 DICKENSON, John. Marianne North: uma naturalista do século dezenove no Brasil?. In.: Cadernos Pagu. n. 15, p. 145-164, 2000.

42 DICKENSON, 2000, op. cit., p. 164.

43 GAZZOLA, Ana Lúcia Almeida. O Brasil de Marianne North: Lembranças de uma viajante inglesa. Estudos Feministas. nº 16, 2 ed. 2008, p. 1031-1045.

44 GAZZOLA, 2008, op. cit., p. 1042.

45 Idem, p. 1043.

46 DICKENSON, 2000, op. cit., p. 157.

47 GLADSTON, Lynne Helen. The hybrid work of Marianne North in the context of nineteenth-century visual practice(s). Inglaterra: Universidade de Nottingham, 2012.

48 DICKENSON, 2000, op. cit., p. 162. 
49 "Um retrato do pitoresco brasileiro", entrevista realizada por Patricia Fachin a Lorelai Kury, em 24 de junho de 2018, publicada na Revista do Instituto Humanitas da Universidade do Rio dos Sinos.

50 REIS, Dennys Silva. História visual da tradução: A iconografia do século XIX no Brasil". vol. 11, n. 5. 2017. Uberlância: Domínios de Lingu@gem, p. 14751504.

51 BURKE, Peter. Testemunha ocular: História e imagem. São Paulo: Unesp, 2017.

52 PANOFSKY, Erwin. Iconografia e iconologia: Uma introdução ao estudo da arte na Renascença. In.: Significado nas artes visuais. São Paulo: Perspectiva, 1976, p. 47-87.

53 Urbe é uma palavra que vem do latim. Sinônimo para a palavra cidade. É um aglomerado de populacional onde ocorre trocas sociais, comerciais, administrativas, educacionais e culturais, localizado em um determinado espaço fixo.

54 Cf. DEAN, Warren. A Botânica e a Política Imperial: Introdução e adaptação de plantas n Brasil Colonial e Imperial. São Paulo:

55 GAZZOLA, 2008, op. cit., p. 1043.

[Artigo recebido em Junho de 2019. Aceito para publicação em Dezembro de 2019] 